Palekha, Yu. I. (2004). Imidzholohiia [Imageology]: navch. posib. dlia stud. vyshch. navch. zakl. Kyiv: Vydavnytstvo Yevropeiskoho universytetu. 323 s. [in Ukrainian].

Sushko, S. (2003). Suchasna model upravlinnia himnaziieiu [Modern model of gymnasium management]. Dyrektor shkoly, litseiu, himnazii. № 3. S. 85-90. [in Ukrainian].
Shavkun, I. H. (2016). Formuvannia imidzhu orhanizatsii [Forming the image of the organization]: navchalnyi posibnyk. Zaporizhzhia: ZNU. $111 \mathrm{~s}$. [in Ukrainian].

Zeliuk, V. V. (2014). Imidzh suchasnoho pedahoha yak trybuna rozvytku innovatsiinoho potentsialu pedahohiv Ukrainy [Image of a modern teacher as a platform for the development of Ukrainian teachers innovative potential]. Imidzh suchasnoho pedahoha. № 1. S. 4-8. [in Ukrainian].

Дата надходження до редакиії: 24.05.2021 p.

\section{Оксана ЛЮТКО,}

кандидат філософських наук, доиент, завідувач кафедри філософії, економіки та менеджменту освіти

Рівненського обласного інституту післядипломної педагогічної освіти, м. Рівне, Украӥна

ORCID: 0000-0003-2853-500X

e-mail: oksanaliutko@gmail.com

\section{Володимир ЗИЛЬ,}

стариий викладач

кафедри філософії, економіки

та менеджменту освіти

Рівненського обласного інституту післядипломної педагогічної освіти, м. Рівне, Україна

ORCID: 0000-0002-8924-0822

e-mail:v.zyl@roippo.org.ua

\title{
ФІЛОСОФІЯ ОЦННВАННЯ НАВЧАЛЬНИХ ДОСЯГНЕНЬ ЗДОБУВАЧІВ ОСВІТИ В КОНТЕКСТІ КОМПЕТЕНТНІСНОГО ПІДХОДУ
}

\begin{abstract}
Анотація. У статті проаналізовано недоліки традииійної системи оцінювання, а також окреслено сутність сучасної філософії оцінювання навчальних досягнень здобувачів загальної середньої освіти в контексті компетентнісного підходу. Оиінювання розглядається як важливий прочес, щуо сприяє індивідуалізації освітнього процесу, підвищенню навчальної мотивачії та самостійності учнів, розвитку їхніх індивідуальних здібностей. Визначено мету оцінювання навчальних досягнень здобувачів освіти. Обгрунтовано необхідність використання формувального оцінювання на будь-якому рівні освіти, оскільки і в Державному стандарті початкової освіти, $і$ в Державному стандарті базової середньої освіти зазначено, шчо вимірювання навчальних досягнень здобувачів освіти
\end{abstract}

відбувається шляхом формувального та підсумкового оцінювання. Окреслено сутність різних видів оцінювання та методи їх реалізації. Наголошено на тому, шо система оиінювання неможлива без інформування учнів про критерії оцінювання та розуміння того, як $i$ за щуо їх оцінюють. Доведено, щуо критерії сприяють об'єктивації оиінювання, а оиінювання з використанням ретельно розроблених критерїв дає змогу зробити ией прочес прозорим і зрозумілим для всіх здобувачів освіти.

Ключові слова: оцінка, оцінювання, система оцінювання начальних досягнень здобувачів освіти, основні види оцінювання, формувальне очінювання, критерій, критерії очінювання завдань. 
Oksana LIUTKO,

Candidate of Philosophical Sciences,

Associate Professor.

Head of Philosophy, Economics

and Management of Education Department,

Rivne Regional Institute

of Postgraduate Pedagogical Education,

Rivne, Ukraine

ORCID: 0000-0003-2853-500X

e-mail: oksanaliutko@gmail.com

Volodymyr ZYL,

Senior Lecturer of Philosophy, Economics

and Management of Education Department,

Rivne Regional Institute

of Postgraduate Pedagogical Education,

Rivne, Ukraine

ORCID: 0000-0002-8924-0822

e-mail:v.zyl@roippo.org.ua

\section{PHILOSOPHY OF EVALUATION OF EDUCATIONAL ACHIEVEMENTS OF PUPILS IN THE CONTEXT OF COMPETENCE APPROACH}

\begin{abstract}
The article analyzes the shortcomings of the traditional system of evaluation. It has been outlined essence of the modern philosophy of evaluation of the academic achievements of students of general secondary education in the context of the competence approach. Evaluation is seen as an important process that contributes to the individualization of the educational process, increasing learning motivation and independence of students, the development of their individual abilities.

The purpose of evaluating the educational achievements of students is determined. The necessity of using formative evaluation at any level of education is substantiated. Since in the State Standard of Primary Education and in the State Standard of Basic Secondary Education it is stated that the measurement of educational achievements of students takes place through formative and final evaluation.

The essence of different types of evaluation and methods of their implementation are outlined. It is emphasized that the evaluation system is impossible without informing students about the evaluation criteria and understanding how and for what they are assessed. It has been proved that criteria contribute to the objectification of evaluation. This shows that evaluation with using carefully developed criteria makes this process transparent and understandable to all learners.
\end{abstract}

Key words: grade, evaluation, evaluation system of student's initial achievements, main types of evaluation, formative evaluation, criterion, criteria for task evaluation.

Постановка проблеми. За останне десятиліття у змісті освіти відбулися значні зміни, зокрема акцент із предметних знань, умінь і навичок як основної мети навчання було перенесено на здобуття знань, форму- вання предметних і ключових компетентностей, розвиток наскрізних (спільних для усіх компетентностей) умінь. Це зі свого боку спричинило низку змін у цінностях і змісті освіти, методах викладання та навчання, системі оцінювання здобувачів освіти тощо.

За компетентнісної парадигми освіти традиційна система оцінювання має низку недоліків, адже:

- якість освіти ототожнюється із кількістю знань, які учень отримав під час навчання;

- виконує функцію зовнішнього контролю успішності учня з боку вчителя і школи;

- не дає повноцінної можливості для розвитку в учнів навчальної самостійності;

- ускладнює індивідуалізацію навчання;

- малоінформативна;

- основний акцент робиться на порівнянні учнів один 3 одним та ін.

Аналіз представлених вище недоліків дозволяє зробити висновок про необхідність використання такої системи оцінювання, яка б не лише давала змогу оцінювати предметні та метапредметні знання, прогрес учнів у навчанні, а й сприяла усуненню негативних моментів у навчанні, індивідуалізації освітнього процесу, підвищенню навчальної мотивації та навчальної самостійності здобувачів освіти.

Аналіз наукових досліджень і публікацій. Усвідомлюючи, що оцінювання $\epsilon$ надзвичайно важливим елементом реформи шкільної освіти, в Україні було видано низку наказів (від 21.08.2013 р. № 1222 та від 13.04.2011 p. № 329 «Про затвердження орієнтовних вимог оцінювання навчальних досягнень учнів базових дисциплін у системі загальної середньої освіти», від 27.08.2019 p. № 1154 «Про затвердження методичних рекомендацій щодо оцінювання навчальних досягнень 
учнів другого класу») і методичних рекомендацій щодо оцінювання результатів навчання учнів 1-4 класів Нової української школи (листи МОН України від 18.05.2018 p. № 2.2-1250 та від 14.08.2019 р. № 1/9-513); оновлено Державні стандарти початкової та базової середньої освіти, навчальні програми, підручники; підготовлено Рекомендації щодо побудови внутрішньої системи забезпечення якості освіти в закладі загальної середньої освіти, де вміщено розділ, присвячений системі оцінювання здобувачів освіти (Бобровський, 2019, с. 87-106).

Теорію та практику формувального оцінювання проаналізовано в наукових дослідженнях і публікаціях учених Н. Бакуліної, П. Блека, Н. Богданець-Білоскаленко, С. Бойцової, С. Калдибаєва, О. Лінник, О. Локшина, В. Топол, Д. Уільяма, О. Фідкевич, Р. Шакірова та ін.

Фахівці Державної служби якості освіти України зауважують, що більшість педагогів і надалі продовжують ставити оцінки за кількість засвоєної інформації, пропущених орфограм чи неправильно розв'язаних задач. Спостереження за навчальними заняттями під час інституційних аудитів закладів загальної середньої освіти Рівненщини засвідчило, що формувальне оцінювання, яке дає змогу відстежити індивідуальний поступ учнів, сформувати в них позитивну самооцінку, застосовується лише вчителями початкової школи. Крім того, педагоги рідко використовують прийоми самооцінювання та взаємооцінювання здобувачів освіти, не аргументують виставлені оцінки, не аналізують допущені помилки, не визначають шляхів покращення результатів навчання та не заохочують до подальшого навчання (Державна служба якості освіти України: вебсайт. Висновки та рекомендації, 2021).

Мета статті - окреслити сутність сучасної філософії оцінювання навчальних досягнень здобувачів освіти в контексті компетентнісного підходу.

Виклад основного матеріалу дослідження. Досить часто терміни «оцінювання» та «оцінка» вживаються як синоніми, хоча насправді вони не є такими. Енциклопедія освіти визначає очінювання як процес, який відбувається постійно: під час роботи на уроці, спостереження за навчальною діяльністю учня, аналізу відповідей, виконання ним різних робіт (Енциклопедія освіти, 2008, с. 630). Відповідно Український педагогічний енциклопедичний словник так трактує дефініцію «оцінка»: це визначення й вираження в умовних знаках - балах, а також в оцінювальних судженнях учителя ступеня засвоєння учнями знань, умінь і навичок відповідно до вимог шкільних програм (Український педагогічний енциклопедичний словник, 2011, с. 338). Отже, оцінювання - це процес, а оцінка - результат проиесу оиінювання.

Основною метою оиінювання навчальних досягнень здобувачів освіти є розуміння ступеня відповідності між запланованими та отриманими результатами навчання. Оцінювання здійснюється для того, щоб:

- звернути увагу учня на цілі навчання та критерії досягнення успіху;

- спрямовувати дії педагога на вдосконалення технологій індивідуального поступу кожного учня, як-от: надавати йому інформацію, необхідну для прийняття рішення щодо подальших кроків у навчанні (на що спрямувати свої зусилля, на що звернути увагу, що поліпшити, а що виправити); освіти;

- формувати навички самооцінки в здобувачів

- регулярно встановлювати зворотний зв'язок 3 учнями;

- мотивувати учнів до подальшого цілеспрямованого навчання;

- надавати учням інформацію про якість їхньої роботи, учителям - про прогрес учнів, а батькам - про рівень досягнення результатів навчання.

Для того, щоб спланувати свої дії щодо забезпечення ефективного оцінювання, педагогам важливо знати мету, критерії та методи основних видів оцінювання. За цими параметрами оцінювання поділяється на такі основні види: діагностичне, формувальне, підсумкове (див. рис.) (Шакіров, Буркітова, Дудкіна, 2012).

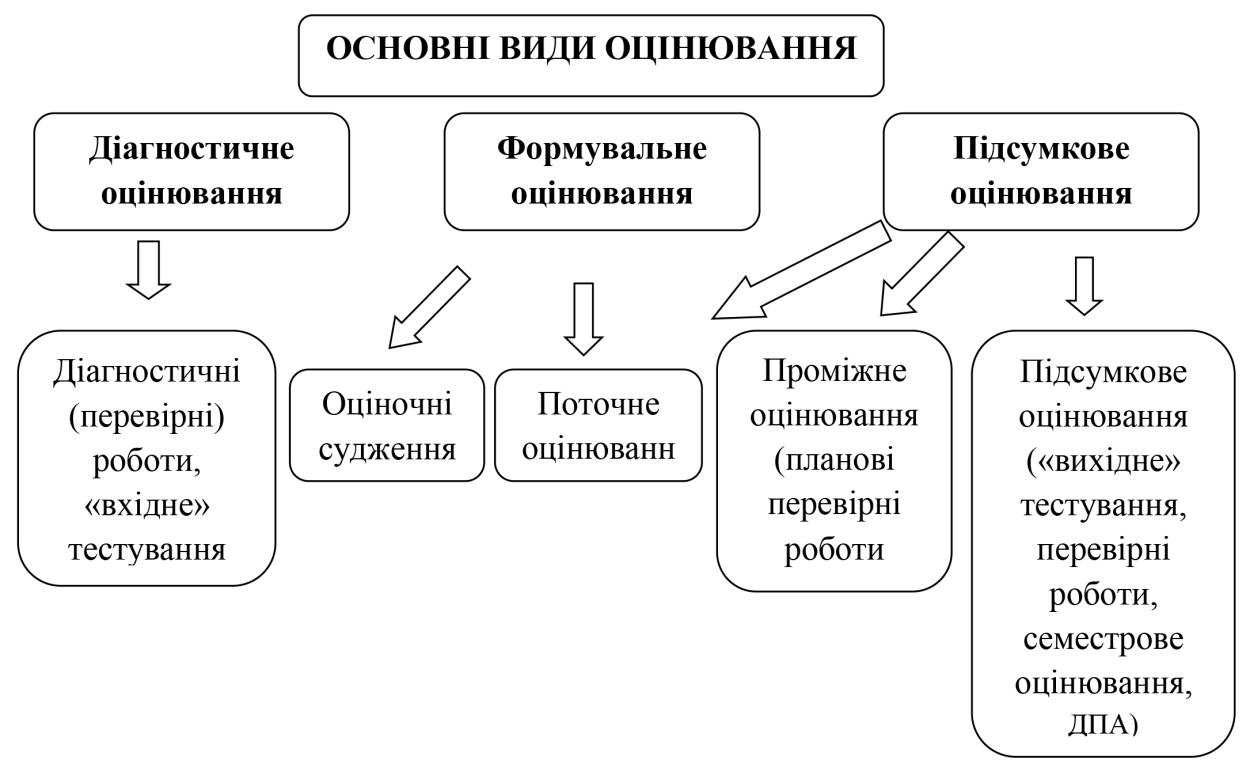

Рис. Основні види оцчінювання 
Діагностичне оцінювання зазвичай проводиться на початку навчального року або на першому занятті 3 вивчення нового розділу з метою визначення початкового рівня сформованості знань, умінь, навичок і компетентностей учнів. Таке оцінювання допоможе вчителеві скорегувати календарно-тематичний план, що відповідатиме запитам учнів, спрогнозувати, а в подальшому - й подолати можливі труднощі у навчанні, створить мотивуючу проблемну ситуацію. Діагностичне оцінювання реалізується через «вхідне» діагностування, «відкриті запитання» та перевірні роботи, під час яких визначається актуальний рівень знань 3 теми (див. табл. 1).

Формувальне оцінювання - це оцінювання прогресу учнів із метою внесення змін до процесу навчання. Поточне оцінювання як складова формувального оцінювання виконує частину функцій такого оцінювання.
Поточне оцінювання зазвичай перетворювалося в самоціль і реалізовувалося на рівні фіксації «знання незнання», «уміння - невміння», тобто так званого накопичення оцінок у журналі.

За компетентнісної парадигми освіти формувальне оцінювання набуває інших рис і функцій. Відповідно сьогодні його мета полягає не в констатації рівня досягнутого навчального результату, а в покращенні процесу навчання учнів, тобто оцінюються індивідуальні досягнення учня незалежно від досягнень інших учнів.

Реалізація формувального оцінювання передбачає використання аналітичних інструментів і прийомів для вимірювання рівня засвоєння знань та прогресу учнів у процесі пізнання (див. табл. 1). Результати такого оцінювання можна застосовувати як для рефлексії педагогічної діяльності, так і вироблення рекомендацій щодо покращення навчання.

Таблиия 1

\section{Методи реалізації діагностичного та формувального оцінювання}

\begin{tabular}{|c|c|}
\hline Вид оцінювання & Методи і прийоми \\
\hline Діагностичне & $\begin{array}{l}\text { - тестування; } \\
\text { - запитання, що стосуються раніше вивченої теми, розділу; } \\
\text { - рефлексивна ситуація, спрямована на прогнозування і роздуми про очікування від вивчення } \\
\text { нової теми; } \\
\text { - «провокація» інтересу до вивчення нової теми («Чи здатен / здатна ти зробити, створити, засто- } \\
\text { сувати ...? Чи знаєте ви, як ...?») }\end{array}$ \\
\hline Формувальне & $\begin{array}{l}\text { - двосторонні картки; } \\
\text { - сигнали рукою («сигнальні картки», «лінійка успіху», «світлофор»); } \\
\text { - мовні вирази (підказки) для побудови відповіді; } \\
\text { - мінітест для оцінювання фактичних знань (тест, що передбачає вибір правильної відповіді з } \\
\text { низки інших відповідей); } \\
\text { - вибірковий тест (картки з літерами, якими голосує учень); } \\
\text { - формувальний тест (лист із тестовими запитаннями, який виконується в малих групах); } \\
\text { - формувальне опитування; } \\
\text { - самооцінювання (учні збирають інформацію про свої знання, аналізують її та роблять висновки } \\
\text { щодо власного прогресу); } \\
\text { - взаємооцінювання (застосовується при оцінюванні творчих робіт, обов’язково вказуючи два } \\
\text { позитивних моменти («дві зірки») та один негативний («побажання») тощо }\end{array}$ \\
\hline
\end{tabular}

Підсумкове оиінювання - це оцінювання, що використовується для узагальнення (підведення підсумків) на тому чи іншому етапі процесу навчання. Мета підсумкового оцінювання - констатувати рівень засвоєння знань, сформованих умінь і компетентностей учнів у певний період часу, визначення відповідності отриманих результатів вимогам Державних стандартів.

За функціонування знаннєвої парадигми освіти підсумкове оцінювання фокусується на знаннях (факти, дати, події, правила, формули), тобто на здатності учнів запам’ятовувати й відтворювати їх. Компетентнісна парадигма освіти передбачає перевірку навичок мислення більш високого рівня, коли учень може об'єднати факти та ідеї, синтезувати, узагальнити, пояснити їх, зробити висновок, інтерпретувати інформацію тощо. Саме тому, розробляючи контрольно-перевірні роботи, варто використовувати адаптовану Л. Андерсон та Д. Кратволем таксономію Б. Блума (Anderson, Krathwohl, 2001).

Таким чином, оцінювання - це основний засіб вимірювання досягнень здобувачів освіти, своєрідна діагностика проблем навчання та здійснення зворотного зв'язку. Воно повинно бути гнучким, психологічно комфортним, багатоскладовим і зрозумілим усім учасникам освітнього процесу. Крім того, оцінювання неможливе без інформування учнів про критерії оцінювання, а також без розуміння того, як і за що їх оцінюють. Вільна онлайн-енциклопедія «Вікіпедія» визначає поняття «критерій» як мірило, вимоги для оцінювання людини, предмета, явища (Вікіпедія. Критерій, 2021). Отже, критерій - цее мірило оцінки; ознаки, на підставі яких виставлясться оиінка.

Розробляючи критерії оцінювання завдань, педагог обов'язково має врахувати: критерії, затверджені Міністерством освіти і науки України, навчальні цілі та зміст уроку, компетентнісний підхід до викладання предмета, а також організаційну форму проведення навчального заняття.

Наведемо приклади критеріїв, за якими можна оцінювати вміння учнів співпрацювати в малій групі (див. табл. 2) (Рамка компетентностей для культури демократії, 2018). 
Критерії оцінювання вміння учнів співпрацювати в малій групі

\begin{tabular}{|c|c|c|}
\hline Критерій & $\begin{array}{c}\text { Описовий рівень сформованості } \\
\text { компетентності }\end{array}$ & $\begin{array}{c}\text { Позначка про досягнення } \\
\text { критерію }\end{array}$ \\
\hline $\begin{array}{l}\text { Вибудовує доброзичливі стосунки з іншими людьми } \\
\text { в групі }\end{array}$ & \multirow[t]{2}{*}{ базовий } & \\
\hline $\begin{array}{l}\text { Працюючи в групі, виконує свою частину групової } \\
\text { роботи }\end{array}$ & & \\
\hline $\begin{array}{l}\text { Працює над досягненням консенсусу заради досяг- } \\
\text { нення цілей групи }\end{array}$ & \multirow[t]{2}{*}{ середній } & \\
\hline $\begin{array}{l}\text { Працюючи в групі, надає іншим важливу чи корис- } \\
\text { ну інформацію }\end{array}$ & & \\
\hline $\begin{array}{l}\text { Викликає ентузіазм у членів групи заради досягнен- } \\
\text { ня спільних цілей }\end{array}$ & \multirow[b]{2}{*}{ високий } & \\
\hline $\begin{array}{l}\text { Працюючи як член групи, підтримує інших учасни- } \\
\text { ків, незважаючи на розбіжності у поглядах }\end{array}$ & & \\
\hline
\end{tabular}

Критерії можуть розроблятися вчителем спільно 3 учнями залежно від ситуації, наприклад, коли учні виконуватимуть якесь завдання вперше. Спільна розробка критеріїв дозволить сформувати в школярів позитивне ставлення до оцінювання і підвищити їхню відповідальність за досягнення результату. Ретельно розроблені критерії дозволять зробити цей процес прозорим і зрозумілим для всіх здобувачів освіти.

Висновки. Реалізувати завдання, окреслені в Державних стандартах початкової та базової середньої освіти, можливо за умови, якщо освітній процес буде спрямовано на розвиток компетентностей, необхідних для людини XXI століття. Це вимагає значних змін у системі оцінювання навчальних досягнень здобувачів освіти.

Система оцінювання включає різні види оцінювання (діагностичне, формувальне, підсумкове), які існують та функціонують паралельно з метою поліпшення якості навчання й викладання. Уміле застосування різних видів оцінювання та методів їх реалізації дозволить педагогові зібрати інформацію про рівень розуміння теми, розвиток компетентностей і наскрізних умінь, диференціювати навчання, тобто врахувати потреби і можливості кожного учня, а учням - контролювати власне навчання і сформувати компетентності, необхідні як у процесі навчання, так і в подальшому житті.

Перспективи подалыших досліджень в означеному напрямі вбачаємо у необхідності розробки критеріїв оцінювання різноманітних видів робіт і форм реєстрації навчальних досягнень здобувачів освіти у процесі використання формувального оцінювання.

\section{СПИСОК ВИКОРИСТАНОЇ ЛІТЕРАТУРИ}

Бобровський, М. В., Горбачов, С. І., Заплотинська, О. О. (2019). Рекомендації до побудови внутрішньої системи забезпечення якості освіти у закладі загальної середньої освіти. Київ: Державна служба якості освіти. $240 \mathrm{c.}$

Висновки та рекомендації. (2021). Державна служба якості освіти України: вебсайт. URL: http:// www.sqe.gov.ua/index.php/uk-ua/16-04-2019/vysnovkyi-rekomendatsii (дата звернення: 12.04.2021).

Енциклопедія освіти. (2008) / Акад. пед. наук України; гол. ред. В. Г. Кремень. Київ: Юрінком Інтер. 1040 с.
Гончаренко, С. У. (2011). Український педагогічний енциклопедичний словник. 2-е вид., допов. і виправ. Рівне: Волинські обереги. 552 с.

Оценивание учебных достижений учащихся: методическое руководство (2012) / сост. Р. Х. Шакиров, А.А. Буркитова, О. И. Дудкина. Бишкек: Билим. 80 с.

Anderson, L., Krathwohl, D. R. (2001). A Taxonomy for Learning, Teaching and Assessing: a revision of Bloom's Taxonomy of Educational Objectives. URL: https://www. uky.edu/ rsand1/china2018/texts/Anderson-Krathwohl\%20 $\% 20 \mathrm{~A} \% 20$ taxonomy $\% 20$ for $\% 20$ learning $\% 20$ teaching $\% 20$ and\%20assessing.pdf. (дата звернення: 24.05.2021).

Критерій. Вікіпедія: вільна онлайн-енииклопедія. URL: https://uk.wikipedia.org/wiki/\%D0\%9A\%D1\%80\% D0\%B8\%D1\%82\%D0\%B5\%D1\%80\%D1\%96\%D0\%B9 (дата звернення: 27.04.2021).

Рамка компетентностей для культури демократії. (2018). Том 2: Дескриптори компетентностей для культури демократії. URL:https:/www.schools-fordemocracy.org/images/documents/87/RF-CDC-vol-2 ua.pdf (дата звернення: 10.06.2021).

\section{REFERENCES}

Bobrovskyi, M. V., Horbachov, S. I., Zaplotynska, O. O. (2019). Rekomendatsii do pobudovy vnutrishnoi systemy zabezpechennia yakosti osvity u zakladi zahalnoi serednoi osvity [Recommendations for involving the internal quality assurance system in general secondary education institutions]. Kyiv: Derzhavna sluzhba yakosti osvity. 240 s. [in Ukrainian].

Vysnovky ta rekomendatsii [Conclusions and recommendations]. (2021). Derzhavna sluzhba yakosti osvity Ukrainy: vebsait. URL: http://sqe.gov.ua/images/materials (data zvernennia: 12.04.2021). [in Ukrainian].

Entsyklopediia osvity [Encyclopedia of Education]. (2008) / Akad. ped. nauk Ukrainy; hol. red. V. H. Kremen. Kyiv: Yurinkom Inter. 1040 s. [in Ukrainian].

Honcharenko, S. U. (2011). Ukrainskyi pedahohichnyi entsyklopedychnyi slovnyk [Ukrainian pedagogical encyclopedic dictionary]. 2-e vyd, dopov. i vyprav. Rivne: Volynski oberehy. 552 s. [in Ukrainian].

Otsenivanie uchebnykh dostizheniy uchashchikhsya: metodicheskoe rukovodstvo [Assessment of student academic achievements: a methodological guide]. (2012) 
/ sost. R. Kh. Shakirov, A. A. Burkitova, O. I. Dudkina. Bishkek: Bilim. 80 s. [in Russian].

Anderson, L., Krathwohl, D. R. (2001). A Taxonomy for Learning, Teaching and Assessing: a revision of Blooms Taxonomy of Educational Objectives. URL: https://www.uky.edu/ rsand1/china2018/texts/Anderson-Krathwohl $\% 20 \% 20 \mathrm{~A} \% 20$ taxonomy $\% 20$ for $\% 20$ learning\%20teaching\%20and\%20assessing.pdf. (data zvernennia: 24.05.2021). [in English]

Kryterii [Criteria]. (2021). Vikipediia: vilna onlain-entsyklopediia. URL: https://uk.wikipedia.org/wiki/ $\%$ D0\%9A\%D1\%80\%D0\%B8\%D1\%82\%D0\%B5\%D1\%

УДК 37.091.4:005.51

DOI: 10.37026/2520-6427-2021-107-3-36-41
$80 \% \mathrm{D} 1 \% 96 \% \mathrm{D} 0 \% \mathrm{~B} 9$ (data zvernennia: 27.04.2021). [in Ukrainian].

Ramka kompetentnostei dlia kultury demokratii [Frameworks for democracy culture competence]. T. 2: Deskryptory kompetentnostei dlia kultury demokratii (2018). URL: https://www.schools-for-democracy.org/images/documents/87/RF-CDC-vol-2_ua.pdf (data zvernennia: 10.06.2021). [in Ukrainian].

Дата надходження до редакиії: 11.06.2021 p.

\section{ОСОБЛИВОСТІ ПЛАНУВАННЯ В УМОВАХ РОЗВИТКУ ОСВІТНІХ СИСТЕМ}

\begin{abstract}
Анотація. У статті досліджено особливості планування в умовах розвитку освітніх систем. Зроблено висновок, що в залежності від фази розвитку закладу як освітньої системи (жорстка система, система з делегованими управлінськими повноваженнями, "м'яка» система, система з мережевою взаємодією, синергетична система) планування його діяльності має здійснюватися на основі диферениійованої участі в иьому прочесі керівниитва, самоврядування закладу та зачікавлених громадських структур.

Підкреслено, що рівень участі самоврядування закладу та громадських структур у плануванні (на основі консультачій чи узгодження позичій з керівництвом та з іншими учасниками освітнього процесу) залежить як від фази розвитку закладу, так $і$ від виду планування (стратегічне, тактичне, оперативне) та
\end{abstract}

особливостей субфункиій планування (планувально-діагностувальної, планувально-иільової, планувально-критеріальної, планувально-програмної, планувально-ресурсної, планувально-інформаційної субфункцій).

Наголошено, що з розвитком освітніх систем у прочесі планування змінюються також форми взаємодії керівництва, органів самоврядування закладу та громадських структур, які стають все більше демократичними - від наказів та інструктажів керівника до нарад при керівникові та консультащій з органами самоврядування закладів, педагогічних (вчених) рад $i$ «круглих столів», конферениій та обговорень на інтернет-форумах, загальних зборів і громадських слухань томо

Ключові слова: освітня система, рівень розвитку, планування, субфункиія, диференційована участь.

\author{
Oleksandr PASTOVENSKYI, \\ Doctor of Pedagogical Sciences, \\ Professor of the Department \\ of Social Sciences and Humanities, \\ Zhytomyr Regional Institute \\ of Postgraduate Pedagogical Education \\ of Zhytomyr Regional Council, \\ Zhytomyr, Ukraine \\ ORCID: 0000-0002-6450-0843 \\ e-mail:al.pastov@gmail.com
}

\section{THE PECULIARITIES OF PLANNING IN THE CONDITIONS OF EDUCATIONAL SYSTEMS DEVELOPMENT}

Abstract. The article examines the peculiarities of planning in the conditions of educational systems development.
It is concluded that depending on the phase of development of the institution as an educational system (being the rigid 